\title{
DIE CHRISTOLOGIE IN DIE OPENBARING VAN JOHANNES, IN HOOFTREKKE BESIKRYWE
}

\author{
Ds. J. J. Engelbrecht jnr.*
}

Wat van die Nuwe Testamentiese Christologie as geheel geld, geld van die Christologie van die Boek „Openbaring van Johannes", in die besonder, naamlik:

1. Dit is ' $n$ leer oor die Persoon en die werk van Jesus Christus. Persoon en werk van Christus kan nie van mekaar geskei word, soos sommige geleerdes wel wou doen deur byvoorbeeld te onderskei tussen die historiese Jesus enersyds en die leer van Jesus andersyds nie. ${ }^{1}$ )

2. Ook hierdie boek in die besonder gee nie direkte uitsprake oor die twee nature van Christus (waaragtige God en waaragtige regverdige mens) of oor die wesenseenheid al dan nie van die Vader en die Seun nie. Soos in die res van die Nuwe Testament, kry 'n mens ook hier die indruk dat die outeur se belangstelling nie gekonsentreer is op ' $n$ wesenschristologie nie, maar op 'n funksionele christologie; ons outeur se christologie is nie "natureleer" nie, maar leer van "n ..gebeure". ${ }^{2}$ ) Hiermee het ons nog nie gesê dat dit geen uitsprake bevat op grond waarvan konklusies oor hierdie aangeleentheid gemaak kan word nie.

3. Die Persoon en die werk van Jesus Christus is nie maar net 'n aanhangsel van hierdie boek nie. ${ }^{3}$ ) Neem die Persoon en die werk van Jesus Christus weg, en die hele struktuur van die boek tuimel inmekaar én die kern van die boek se boodskap, naamlik kúrios Christós, wat weer kom as Regter vir die wêreld, maar as Heiland vir die getroues, "hulle wat oorwin", is daarmee heen. Trouens, dan is dit nie meer die moeite werd om wat van die boek oorbly, te lees of selfs te behou nie. Ja, hierdie boek verkondig by uitstek die gekruisigde en verhoogde Christus, kúrios kuriôn, basileus basileôn.

4. Ten spyte van meningsverskille en selfs verwarring wat daar cor die uitleg van hierdie boek in fyn besonderhede mag bestaan. is dit duidelik dat hierdie boek, netsoos die ander geskrifte van die Nuwe Testament, die dinge wat in die sterwe van Christus plaasgevind het, as die keerpunt van die tye beskou. Die feit dat

* Skripsie voorgelê ter vervulling van 'n deel van die vereistes vir die D.D.eksamen aan die Universiteit van Pretoria.

1) O. Cullmann: Die Christologe des Neuon Testaments 1957, bls. 336.

2) O. Cullmann: a w.. bl. 9, 336v.

3) G. Sevenster: De Christologie van het N.T., bls. 272, 281. 
Christus reeds in oorwinning behaal het (vergelyk 12: 10, 11; $55 ; 5: 12$ ), is die rede waarom daar só troostend oor ' $n$ komende oorwinning gespreek kan word. ")

Ons beoog om in breë trekke die Christologie van die boek „Openbaring" aan die hand van die belangrikste Christologiese benaminge in die boek te behandel. By die keuse en indeling van die benaminge het ons ons veral laat lei deur Oscar Cullmann in sy bekende werk: "Die Christologie des Neuen Testaments" wat in 1957 verskyn het.

\section{Christus}

Wanneer ' $n$ mens iets wil skryf oor die christologie van 'n bepaalde Bybelboek, lyk dit vir my voor die hand liggend dat 'n mens byna in die eerste plek sal probeer vasstel of en hoe die term "Christus" in die betrokke boek gebruik word, om dan daarná aandag te skenk aan ander benaminge vir Christus en moontlike uitsprake wat ook by wyse van implikasie op die Persoon en werk van Jesus Christus betrekking mag hê.

Bykans onmiddellik trek dit ' $n$ mens se aandag dat hierdie "titel" wat al die eeue deur so geliefd by die Kerk was en nog steeds is, in "die openbaring van Jesus Christus wat God Hom gegee het om aan Sy diensknegte te toon wat gou moet gebeur ...." baie selde in hierdie boek gebruik word.

Dit is ook opmerklik dat daar soms sprake is van hô Christós (met die lidwoord), waaruit blyk dat dit nog nie 'n eienaam is nie, maar wel deeglik 'n titel (vergelyk $20: 4,6$ ). ${ }^{1}$ )

"Christus" is afgelei van die woord chriô en is die vertaling van die Hebreeuse Mâsjiach en die Aramese Mesjiach waarvan die status determinatus Mesjîcha is. In Grieks word dié Aramese woord ook met Messías weergegee en dit beteken .Gesalfde". ${ }^{2}$ ) Jesus Christus beteken Jesus Messias. ${ }^{3}$ ) Hoewel die woord "Christus" reeds by Paulus die tendens openbaar om tot eienaam te verstar, moet ons by die lees van die Nuwe Testament, dus ook van die boek "Openbaring", in gedagte hou dat in die bewussyn van die Nuwe Testamentiese outeurs die betekenis Jesus Messias, ten minste nog op die agtergrond staan. ${ }^{3}$ )

4) G. Sevenster, a.w., bl. 273. 281.

1) Sevenster, a.w., bl. 275.

2) Sevenster, a.w., bl. 73.

3) O. Cullmann: a.w., bl. 112 
Daarom is dit noodsaaklik om eers kortliks aandag aan die Ou Testamentiese agtergrond van die Messiasbegrip te skenk.

1. Die Messias in die Jodendom.

Die deelwoord „Masjiach" beteken „Gesalfde”, en word in hierdie sin veral gebruik om die koning van Israel aan te dui. Hy is "die gesalfde van Jahwe" (1 Sam. $9: 16 ; 24: 7$ ).

Die benaming is egter ook gegee aan elkeen wat van God ' $n$ besondere opdrag met betrekking tot Sy volk ontvang het, byvoorbeeld ' $n$ priester (Ex. $28: 41$ ) en ' $n$ profeet (1 Kon. 19: 16). Selfs ' $n$ heidense koning soos Cyrus kry hierdie titel as hy as uitvoerende orgaan van die Goddelike heilsplan funksioneer (Jes. $45: 1)^{4}$ )

'n Misverstand wat miskien dikwels voorkom, is dat die Joodse Messiasverwagting geheel-en-al politiek en nasionaal bepaal sou gewees het. Dit kan hoogstens veronderstel word dat hierdie politieke Messianisme steeds 'n belangrike element in die verwagting van ' $n$ deel van die volk gebly het. Op grond van byvoorbeeld 11 Sam. 7: 16 (die belofte aan Dawid), Joh. 6: 15; Mk. $11: 10$; $15: 2$, 9, 32; (vergelyk Hand. $5: 34$ - 37) en Psalms van Salomo 17, kan 'n Messiasfiguur afgelei word wat aan die nasionale verwagting verbonde is. Sy eerste taak sal wees om Israel in sy ou glorie te herstel en die heidense onderdrukkers te verjaag.

Maar daarnaas en baie nou hieraan verbonde, is daar 'n Messiasgestalte met gans ander trekke : 'n hemelse figuur wat aan die einde van die dae as regter sal optree (Dan. 7) en die brenger sal wees van 'n heilstyd waarin vrede en geregtigheid sal heers. (Vergelyk Jes. $9: 5,6 ; 11: 1-9$; Jer. $23: 5 ; 6: 33 ; 33: 14-$ 17, Eseg. $34: 23-30 ; 37: 24$; Ps. $2: 2 ; 18: 51$ ). Hier sal die werk van die Messias dus wees om die sonde te bestry, gerig oor die sondaars uit te oefen en brenger te wees van 'n heeltemal nuwe wêreld.

Dit is nie geregverdig om ' $n$ skerp skeidslyn tussen die twee Messiasverwagtinge te trek nie. Daar is hoogstens ' $n$ onderskeiding moontlik. ${ }^{5}$ )

Hoewel daar volgens die Ou Testament (Ps. 110; Sag. 3-14) en die buite-bybels Joodse apokaliptiese literatuur ${ }^{6}$ ) ook soms 'n priesterlike Messias verwag word, byvoorbeeld uit die stam

4) o. Cullmann: a.w.. bl. 114

5) Sevenster: a.w., bi. 75, 76.

6) Test. XII Patriarge: Test. v. Levi 8: 12-15; Ordereël (Qumranrolle). 
van Levi ${ }^{7}$ ) of spesifiek uit die nakomelinge van Sadok, ${ }^{8}$ ) is dit in hoofsaak so dat die Joodse Messias uit die Dawidiese koningshuis kom en daarom word hy ook ,die seun van Dawid" (Matt. 20 : 30, 31) genoem.

\section{Jesus en die Messias.}

Veral op grond van Mk. 14:61; $15: 2$ vv en $8: 27 \mathrm{vv}$ en die paralelle van dié tekste, lyk dit of ons moet konkludeer dat Jesus ten opsigte van die titel "Messias", die grootste terughoudendheid aan die dag gelê het en die suiwer politieke gedagtes wat hoofsaaklik daaraan gekoppel was, selfs as 'n sataniese versoeking beskou het. Op beslissende plekke het Hy die titel „Messias" met die titel "Seun van die Mens" vervang, onder andere omdat aan laasgenoemde minder assosiasies van suiwer politieke aard verbind was. Teenoor die verkeerde politieke Messiasbeskouinge, het Hy bewustelik die Ebed Jahwevoorstellinge gestel.

Uit die sitaat van Ps. 110 in Jesus se antwoord aan die hoëpriester (Mk. 14 : 62 par.) lyk dit egter waarskynlik dat Hy die gedagtes oor 'n toekomstige heerskappy oor die wêreld in sy verwagting opgeneem het, hoewel in gewysigde vorm.

Waar ander Hom "die Seun van Dawid" noem, wys Hy dié titel dan ook nie af nie (Mk. $10: 47$; Luk. $18: 38$; Mt. $9: 27$ e.a.), maar Hy verwerp beslis baie van die gedagtes wat deur Sy tydgenote aan dié begrip gekoppel was. ${ }^{9}$ )

\section{Die Oergemeente en die Messias.}

In die lig van die Paasgebeure en as gevolg van die verwagting van die spoedige voleinding, het die uitspraak: „Jesus is die Messias (Christus)", vir die Palestynse oergemeente spoedig tot belydenis geword.

Hierdie titel was vir die vroeë Christene ook tot groot hulp om die Jode te laat verstaan waárom hulle in Jesus geglo het.

'n Teologiese grond was dat Jesus op grond van Sy dood en opstanding tot Messias (Christias) geproklameer is.

Die oerchristendom het nie net die terminologie wat op die Messias van toepassing was oorgeneem nie, maar het, al is dit dan ook in gewysigde vorm, spesifieke gedagtes van die Joodse

7) Test. keri.

8) Sadokitiese Dokument XIV. 19; XIX. 10. D. S. Russell : The Method and Message of Jew.sh Apokalyptic, bl. 320 v.v.

9) O. Cullmann: a.w., bl. 126, 127, 128, 134. 
Messiasverwagting in die lig van die vervulling op Jesus toegepas, en wel in drie-erlei sin:

(a) Jesus het as Seun van Dawid op aarde verskyn.

(b) Hy oefen die Koningsheerskappy oor Sy gemeente uit.

(c) Aan die einde verskyn $\mathrm{Hy}$ as Messias op die aarde. ${ }^{10}$ )

4. "Christus" en "Die Christus” as Benaminge of Titels in .Openbaring."

Die volgende tekste is hier ter sake : $1: 1,2,5,6 ; 11: 15$; 12: 10v; $20: 4$ en 6 .

In hoofstuk 1 vers 1 en 2 lees ons „Die openbaring van Jesus Christus wat God Hom gegee het om aan sy diensknegte te toon wat gou moet gebeur, en wat $\mathrm{Hy}$. . . aan sy dienskneg Johannes te kenne gegee het, wat getuig het van die Woord van God en die getuienis van Jesus Christus".

Hierdie vers maak deel uit van die opskrif van die boek; dié opskrif bestaan uit verse 1, 2 en 3 en handel oor die oorsprong van die Openbaring, die Draer en inhoud daarvan en die ontvangers daarvan.

Ons vestig die aandag op die volgende:

(1) In die benaming "Jesus" lê 'n herinnering opgesluit aan die feit dat die Een wat hierdie openbaring van God ontvang en aan Johannes deurgegee het, ' $n$ historiese Figuur is : $\mathrm{Hy}$ is Israeliet van geboorte, die Wortel van Dawid, die Leeu uit die stam van Juda, Een wat deursteek was $(1: 9 ; 12: 17 ; 14: 12 ; 5: 5 ; 1: 7)$ ens.

(2) Hierdie Jesus is die Gesalfde van God, die Messias (Jesus Christus).

(3) Jesus Christus ontvang hierdie openbaring van God. Dit dui daarop dat Jesus Christus nie ' $n$ tweede God is nie. Immers, in hierdie heilshandeling, hierdie openbaring aan die gelowiges, is daar ' $n$ sekere ondergeskiktheid van Jesus Christus aan God wat Hom die apokalips gee om deur te gee. ${ }^{41}$ )

(4) Ton logon tou Theou kai tên marturian lesou Christou : Hier het ons te doen met 'n subjektiewe genitief en die bedoeling is dus: „die openbaring wat deur God gegee

10) O. Cullmann: a.w., bl. 134, 135, 136, 137.

11) R. H. Charles: Revelation I, bl. 6 , xii. Ons bedoel geen subordinasionisme nie. 
is en waarvan deur Jesus Christus getuig is". In $1: 9$; 6: 9 en 20: 4 beteken dit die christelike openbaring as geheel, maar in hierdie passasie is dit beperk tot die woorde wat op hósa eiden volg - dit wil sê die openbaring wat in hierdie boek gemaak word. ${ }^{12}$ )

Deur Sy lyde en dood is Jesus Christus in ' $n$ besondere sin "Getuie" (ho martus ho pistes) en Sy werk dus „getuienis" (marturía).

Die werkwoord „om te getuig" (marturein) het 'n heroiese klank (dink aan bloedgetuie = (martus), maar ook 'n profetiese newesin (19:10) netsoos „dienskneg" (doûlos) ${ }^{13}$ ).

(5) Die feit dat dit nie heeltemal seker is of die engel van God of van Christus is nie (dià toû ângeloû aûtoû) dui daarop dat Christus ook deel het aan die Goddelike natuur of wese.

Openb. 1: 5v lui so: „... en van Jesus Christus, die getroue getuie, die eersgeborene uit die dode en die owerste oor die konings van die aarde! Aan Hom wat ons liefgehad het en ons van ons sondes gewas het in sy bloed en ons gemaak het konings en priesters vir sy God en Vader, aan Hom die heerlikheid en die krag tot in alle ewigheid!"

Dit is die laaste keer dat die uitdrukking "Jesus Christus" in "Openbaring" voorkom.

Die hooftitel of begrip in hierdie verse is "Jesus Christus". en hierdie Gesalfde word dan nog verder omskryf as:

(a) „die getroue getuie",

(b) "die eersgeborene uit die dode",

(c) „die Owerste oor die konings van die aarde".

Soos die Godsnaam drieledig is, is ook die omskrywinge by die Naam van Christus drieledig, naamlik: gestorwe, begrawe, verhoog. Vergelyk vir die vorms van hierdie omskrywings, Ps. 89 : 28, 38. ${ }^{14}$ )

In die Nuwe Testament word .ggetuie" slegs hier en in 3:14 van Christus gebruik. Hy is die Ware Getuie van elke Godsopenbaring (vergelyk Joh. $18: 37$; Ps. $89: 28,38$ ). ${ }^{15}$

12) R. H. Charles: Revelation 1928 (The International Critical Commentary) ad loc.

13) E. Lohmeyer: Die Offenbarung des Johannes (H. z. NT 16) 1953 ad loc.

14) E. Lohmeyer: a.w., ad loc.

15) R. H. Charles: a.w., ad loc. 

het. ${ }^{16}$ )

Christus is Getuie omdat Hy Sy getuienis met die dood beseël

Die "eersgeborene uit die dode" (vergelyk Kol. $1: 18 ; 1$ Kor. 15: 20; Kol. 1: 15; Hebr. 12:23). In hierdie geval is dit nie 'n tydsaanduiding nie, maar ' $\mathrm{n}$ aanduiding van soewereiniteit : $\mathrm{Hy}$ is die Heerser oor die dooies, die Regeerder oor die lewendes. ${ }^{17}$ )

"Eersgeborene" is 'n Joodse Messiaanse eretitel. ${ }^{18}$ )

Jesus word deur Sy opstanding die „eersgeborene uit die dode" (Vergelyk prodromos in Hebreërs en âparchê tôn kekoimômenôn in Rom. 8:29; Kol. 1:18). In $1 \mathrm{Kol} 15: 12$ vv word die verband tussen Jesus se opstanding en ons s'n beskryf. ${ }^{19}$ )

As die Verhoogde is Hy aangestel as Vors oor alle konings van die aarde, as die Een wat alle mag en krag in Sy hand hou (vergelyk Matt. 28 19; Filip. 2: 11; Ef. 1 : 20 vv; Jes. $55: 4$ ).

Die lofprysing waartoe die siener oorgaan, is van toepassing op Christus, is ook drieledig ingedeel en wys op die heilswerk van Christus. ${ }^{20}$ )

In verband met die besondere verhouding tussen Christus en God, is dit belangrik om daarop te let dat God in hierdie boek nooit die "Vader" van die gelowiges genoem word nie. Dit word slegs van Sy verhouding tot Christus gesê, soos byvoorbeeld hier in $1: 6$. Dit is verder belangrik dat die doksologie wat in die res van die Ou én Nuwe Testament net op God betrekking kan hê (nie op 'n skepsel nie), hier op Christus toegepas word (vergelyk 5: 13; $7: 10 ; 11$ Petr. 3 : 18; 11 Tim. 4 : 18, Hebr. 13 : 21; 1 Petr. $4: 11) .{ }^{21}$ )

Vergelyk in verband met die unieke verhouding tussen God en Christus, ook die feit dat Christus saam met Hom die Gewer van die genade en vrede $(1: 4 b)$ is.

Nadat die sewende basuin geblaas is, hoor Johannes luide stemme in die hemel, wat sê : „Die koninkryke van die wêreld het die eiendom van onse Here geword en van sy Christus, en Hy sal as Koning heers tot in alle ewigheid". (11:15).

Verse 15-18 wat skynbaar prolepties in uitkyk is, bevat

16) E. Lohmeyer: a.w., ad loc; vgl. I Tim. 6:13; Openb. 2:13.

17) R. H. Charles: a.w., ad loc; 3:14.

18) E. Lohmeyer: a.w., ad loc.

19) O. Cullmann: a.w.. bl. 101.

20) Eduard Lohse: Die Offenbarung des Johannes (Dos. N.T.D. 11) - 1966. ad loc.

21) E. Lohmever: a.w., ad loc. 
twee lofliedere. Volgens Charles ${ }^{22}$ ) word daar in die eerste een (11:15) gejuig oor die goddelike verowering van die wêreld asof dit alreeds bereik is, en oor die tot standkoming van die millennium koninkryk (21: 9 -22: 2; $20: 4-6$ ) en kondig dit die koms aan van die ewige koninkryk wat aan die einde daarvan sal aanbreek (21: $1-4 ; 22: 3-5)$.

Die tweede loflied (v. 17, 18) erken eers die vestiging van Gods soewereinteit in die millennium koninkryk (17 c.d.) en die opstand van Gog en Magog aan die einde daarvan, en kondig dan aan dat die tyd vir die laaste oordeel, vir die vergoeding van die gelowiges en die verderwing van diegene wat die wêreld verderf (v 18), nou gekom het. Behalwe in die laaste sinsnede, word die chronologiese volgorde van ontwikkeling gevolg.

Volgens Lohmeyer ${ }^{23}$ ) is die uitdrukking "van onse Here" ens. ' $n$ Ou Testamentiese uitdrukking, ontleen aan die Messiaans vertolkte Ps. $2: 2$ (vergelyk Henog $48: 10 ; 5: 2 ;$ Ps. Sal. $17: 36$; $18: 6,8$; Lk. $2: 11$ ).

Die uitdrukking "koninkryk van die wêreld" kom slegs hier en in Matt. 4: 8 voor. Daar én hier is die gedagte dat die wêreld in die hede ver van God is en deur die duiwel beheers word dat dit eers eers in die eindtyd die eiendom van God word.

Volgens Charles ${ }^{24}$ ) begin die koninkryk met die millennium (21:9-22; 20:4-6), wat ná die laaste oordeel oorgaan in die ewige koninkryk van God (21: 1 - 4; $22: 3-5)$.

Die koninkryk van God en Christus is volgens hom een (vergelyk Ef. $5: 5$; 1 Kor. $15: 24$ - 28; Ef. $1: 23$; Kol. 3:11; Dan. $2: 44 ; 7: 14$, 27; Lk. $1: 33$ ). ${ }^{25}$ )

E. Lohse ${ }^{26}$ ) sê in hierdie verband dat in hierdie lofsang die finale (endgültigen) oorwinning van God geprys word. Daarmee word vooruit gesien: Dat die Here en Sy Gesalfde (vergelyk Ps. 2:2) die heerskappy begin uitoefen (die Herrschaft antreten) is só seker, dat reeds nou al in die tydsvorm van die verlede, daaroor gespreek kan word (vergelyk 7:9 - 17; $10: 7$ ).

Aan die probleem van die verhouding tussen die huidige heerskappy van die verhoogde Christus en Sy heerskappy in die millennium, sal by die uitleg van hoofstuk 20:4 - 6 meer aandag geskenk word. ${ }^{27}$ )

22) a.w., ad loc.

23) a.w., ad loc.

24) a.w., ad loc.

25) a.w., ad loc.

26) a.w., ad loc.

27) E. Stauffer D.e Theoloqie des N.T. 1948, bl. 106, 197. 
Johannes sien die komende vervulling van Daniël se profesie dat die "koninkryk van die wêreld" die koninkryk van onse Here (kurios) sal word - nie die van kúrios kaisar nie. ${ }^{28}$ )

Nadat Johannes gesien het hoe dat die Satan en sy engele uit die hemel op die aarde neergewerp is (12:9), hoor hy 'n luide stem in die hemel sê : Nou het die heil en die krag en die koningskap die eiendom van onse God geword, en die mag van sy Christus; want die aanklaer van ons broeders is neergewerp, hy wat hulle aanklaag voor onse God, dag en nag" (12:10).

Hierdie hele hoofstuk oor die vrou en die draak en die manlike Kind, is moeilik om te verstaan.

De Zwaan ${ }^{29}$ ) sien in die beelde van hierdie hoofstuk allerlei astrale en mitologiese motiewe uit Persiese, Chaldeeuse en Hellenistiese gedagtewêreld, wat deur Johannes "gekersten" en vir sy boodskap bruikbaar gemaak is. In die taal van hierdie mitologie sê Openb. 12 dan dat nie een van die mitologiese magte die ware Verlosser is nie, maar dat in Jesus en die Kerk wat Sy liggaam is, beliggaam is die dinge wat die mense van die opperste godheid as heilsdaad gehoop het. Want die Hemelse Moeder is nie alleen die moeder van die Messias nie, maar ook-vers 17-die moeder van die gelowiges.

Hoofstuk 12 sien die konflik tussen goed en kwaad as 'n kosmiese stryd - nie ' $n$ stryd wat sy oorsprong op die aarde het nie, ${ }^{30}$ ) (vergelyk Ef. $6: 12$ vv; Jes. $24: 22$; Dan. 12; Ef. $1: 3$, 10; Luk. 10:18). Dié konflik word nie beëindig voordat die koninkryk van hierdie wêreld die koninkryk van die Here en sy Christus geword het nie.

Die kerngebeurtenis van hierdie hoofstuk is die geboorte van die Kind wat tot Wêreldheerser en Wêreldkoning bestem is. Vir die siener lê die klem nie soseer op die geboorte assulks nie, maar daarop dat daarmee die wending in die tyd gekom het, omdat die heerskappy van God gekom het en die draak neergewerp is. ${ }^{31}$ )

Die dúnamis is die krag van God wat tot openbaring gekom het in die oorwinning oor die draak.

Die exousía is die gedelegeerde mag van die Messias.

Die koninkryk is die ryk, ongedeel en ongekwalifiseerd (vergelyk $11: 15$; Ps. $2: 26$ ). ${ }^{32}$ )

28) A. Richardson: a.w., bi. 91

29) Prof. Dr. J. de Zwaan: De Openbaring van Johannes - 1929. bl. 26 - 33

30) Charles: a.w., ad loc.

31) Lohmever: a.w., ad loc

32) Charles: a.w.. ad loc. 
By „koninkryk" ontbreek die "van die wêreld” van 11:15; daárdie lied sien reeds op ' $n$ later tyd of die voleinding, terwyl hierdie een in 12:10 slegs sien op wat so pas verkry is. ${ }^{33}$ )

Wat die uitleg betref, is Openb. 20:4-6 seker een van die mees omstrede gedeeltes uit die ganse Nuwe Testament. Skynbaar word selfs deur teoloë wat wyd uiteenlopende standpunte inneem, met mekaar hieroor saamgestem, en dit is die belangrikste : dat dit hier gaan om heerskappy wat uitgeoefen word deur die verhoogde Christus. Of die millennium, die koninkryk strek vanaf die opstanding en hemelvaart van Christus tot met Sy wederkoms (vergelyk Augustinus se beskouing in navolging van Ticonius) en of dit gesien word as 'n bepaalde toekomstige fase van die Koningsheerskappy van Christus (vergelyk O. Cullmann ${ }^{34}$ ), dit staan in elk geval vas: Die Gestorwe maar Verrese Jesus Christus het opgevaar na die hemel en sit reeds aan die regterhand van God die Vader, die Almagtige, met alles wat daardeur geïmpliseer word (vergelyk $1: 8$; Mk. $16: 19$; Kol. $3: 1$ ).

In Openb. 20: 4 lees ons dan: „En ek het trone gesien, en hulle het daarop gaan sit, en aan hulle is die oordeel gegee; en ek het die siele gesien van die wat onthoof is (mense dus wat reeds gesterf het - J.E.) oor die getuienis van Jesus Christus en oor die woord van God . . . . en hulle het geleef (beter vertaling?: en hulle het herleef / begin leef) - en as konings geregeer saam met Christus die duisend jaar lank". ${ }^{35}$ )

In vers 6 staan daar onder andere „.... hulle sal priesters van God en van Christus wees en sal saam met Hom as konings regeer duisend jaar lank".

Charles ${ }^{36}$ ) som hierdie hoofstuk in hoofsaak só op: Nou dat Rome geval het (hoofstuk 18), die vyandige nasies vernietig is en die twee diere in die vuurpoel gewerp is $(19: 19,20)$, bly geen struikelblok meer oor vir die manifestasie van die koninkryk nie, behalwe die teenwoordigheid van die Satan op die aarde. Daarom word sy aktiwiteite beëindig deur hom geboeid vir 1,000 jaar in die afgrond op te sluit $(20: 1-3)$. Die lotgevalle van die Satan word bepaal deur die belangrikste gebeurtenisse in die lewe van Christus. In hoofstuk 12 word Satan se uitwerping uit die hemel in verband met die geboorte en hemelvaart van Christus gebring. Op aarda het hy getier teen die volgelinge van Christus, maar by

33) Lohmever: a.w., ad loc; E. Stauffer: a.w., bl. 120.

34) a.w.. bl. 137, 232, 233, 234, 235.

35) De Žwaan: a.w.. bl. 119: en zii werden levend en zij werden Koningen; vergelyk vers 5 . Afrikaanse vert.: het nie herlewe nie.; $C$. $H$. Charles a.w., ad loc.

36) a.w., ad loc. = came to life. 
Christus se tweede koms en Sy omverwerping van Satan se werktuie, word Satan self in die afgrond gewerp en die millennium koninkryk word opgerig. Aan die einde van hierdie koninkryk word Satan losgelaat en finaal oorwin en dan in die vuurpoel gegooi en die nuwe hemel en die nuwe aarde verskyn waarin die gemeenskaplike troon van God en van die Lam is.

Oscar Cullmann ${ }^{3 i}$ ) sê in hierdie verband: "Das Tausendjährige Reich . . . gehört zeitlich in den Endakt dieser Herrschaft Christi, der mit seiner Wiederkehr beginnt und so schon in den neuen Aön hineinragt. Dass diese Herrschaft Christi schon lange vorher begonnen hat, zeigt sich gleich am Anfang der Apokalypse, wo wir lesen, Christus habe die Macht über den Tod und den Aufenthalt der Toten (Apk. 1, 18), er sei der Herrscher der irdischen Könige (Apk. 1,5). Aber auch weiter : er regiere die Völker mit eiserner Rute (Apk. 12, 5; 19,5) und sein Name sei, "König der Könige" und "Heer der Herren (Apk. 19, 6)".

In verband met die heerskappy van Christus in die hede én die toekoms, sê Cullman onder andere ${ }^{38}$ ) dat die tyd van die Kerk volkome saamval met hierdie tyd van die heerskappy van Christus, ook wat die kenmerkende spanning tussen hede en toekoms betref én die heenreik in die nuwe aioon.

Die tyd van die heerskappy van Christus en van die Kerk is die tyd van die Heilige Gees en laasgenoemde het eers "Gemeingut" geword sedert Christus verheerlik is (Joh. 7:39). Ook in Matt. 16: 18 waar die geinkarneerde Jesus spreek, heet dit in die futurum ,Ek sal my Kerk bou (oikodomésô), dit wil sê ná dood en opstanding. Ook die einde van die Kerk is identies met die van die heerskappy van Christus : "es fällt wie jenes mit Christi Wiederkunft zusammen, ragt aber ebenfalls in charakteristischer Weise noch in die Endzeit hinein. So wird beim Schlussakt Christus umgeben sein von denen, die auf Erden seine Urkirche gebildet haben : die Apostel werden auf zwölf Thronen sitzen (Mt. 19, 28) und werden mit ihm regieren (Apk. 5, 10; 20, 4; 11 Tim. 2, 12). Die "Heiligen" d.h. alle Glieder der Kirche, werden die Engelmächte richten (1 Kor. 6, 2f). Das "tausendjährige Reich" der Apokalypse wird daher die Kirche jener Zeit, die Kirche der Endzeit sein".

In die Joodse apokaliptiese literatuur uit die tyd van die Nuwe Testament, was die voorstelling van 'n Messiaanse tussenryk wat die einde én die komende Godsheerskappy sal voorafgaan, bekend (Henog - Apk. 91: 12 vv; 93; Sibyl. Or. 3:652vv; IV Esra 7:28v;

37) a.w., bl. 233.

38) a.w., bl. 233. 
Baruch Apk. 29: 3; 40: 3 ea). Die Joodse verwagting van 'n tussenryk het in 'n verchristelike vorm in "Openbaring" ingang gevind.

As ons weer 'n keer noukeurig na die teks van Openb. 20:4 kyk, lyk dit tog of verwys word na 'n tyd wanneer minstens sommige gelowiges al hul opstanding uit die dood agter die rug het - of in elk geval hulle dood! Andersyds is die Laaste Oordeel ook dán nog in die toekoms, omdat „die ander dode . . . . . nog nie herlewe (het) nie." (Vergelyk ook $20: 11-15$ ).

KONKLUSIE : Ons tekste verwys na 'n tyd wat nog kom; 'n tyd wanneer Christus en minstens sommige van die afgestorwe gelowiges, wat weer opgewek sal wees, in 'n besondere sin op hierdie aarde heerskappy sal uitoefen - in ' $n$ ander sin as wat Christus reeds sedert Sy hemelvaart heerskappy uitoefen.

Natuurlik bly ná hierdie voorlopige konklusie nog baie onopgeloste probleme oor, maar dit lyk vir my of ' $n$ mens ten minste dié dinge kan en moet aflei uit Openbaring $20: 4$ - 6 .

\section{SAMEVATTING :}

Onder die benaming of titel „Christus", word in hierdie boek verwys na:

(a) Die aardse werk van Jesus. ${ }^{39}$ )

Byvoorbeeld die verwysings na $S y$ dood en opstanding: $1: 5 ; 1: 9 ; 12: 17 ; 14: 12 ; 5: 5$.

(b) Die toekomstige werk van Jesus.

Byvoorbeeld die verwysings na Hom as die strydende Messias (12:10; $11: 15)$; die Leeu (5:5); die Wortel van Dawid; Sy heerskappy as Messias (Christus) tydens die millennium : 20:4-6.

(c) Die huidige werk van Jesus.

Byvoorbeeld Owerste oor die konings van die aarde, (1: 5; $2: 10 \mathrm{vv}$ ).

(d) Die Pre-eksistensie van Jesus.

Al die uitsprake waardeur Sy Godheid geïmpliseer word, byvoorbeeld in die doksologieë: $1: 6$.

39) Vir dié skema, sien 0. Cullmann: a.w., bl. 1 VII, VIII. 
Hier het ons te doen met die mees gebruikte en belangrikste aanduiding van Jesus Christus in die hele boek "Openbaring". Dit word nie minder as 28 of 29 keer gebruik nie. Die wortels van hierdie begrip lê diep in die Ou Testament. Daár is dit 'n veelvuldige gebruikte simbool om baie dinge voor te stel, byvoorbeeld argeloosheid (Jer. 11:19; Ecclesiasticus 13:17; vergelyk ook Jes. $11: 6$ ); die lam was 'n simbool van lyding sonder om te kla (Jes. 53:7); 'n lam is gebruik as brandoffer, as gawe aan God (Gen. $22: 8$ ); die paaslam het gedien ter herinnering aan die verlossing uit Egipte (Ex. 12:3 vv, 11 en 14); 'n lam is gebruik as soenoffer; lammers is daagliks by die tempel as oggend- en aandoffers geslag.

In die apokaliptiese literatuur kry ons ook die gedagte van 'n voorbok wat die kudde lei en teen roofdiere beskerm (Henog $89 \mathrm{vv}$ ).

Waar 'n ryk verskeidenheid beelde tot die Nuwe Testamentiese gebruik bygedra het, is dit by die eksegese van ' $n$ bepaalde Skrifgedeelte, verstandig om daarmee rekening te hou dat ál die verskillende beelde waarskynlik bewustelik of onbewustelik in die gemoed van die outeur aanwesig is. ${ }^{1}$ )

Wat die verband tussen die Vierde Evangelie en Openbaring oukal mag wees, is dit seker nie sonder belang dat dit die enigste twee boeka in die Nuwe Testament is waarin uitdruklik na Jesus Christus as die Lam (van God) verwys word nie. Die Evangelie van Johannes gebruik natuurlik die woord ho amnos, terwyl Openbaring to arnion gebruik.

In Openbaring het die Lam 'n tweevoudige karakter:

(1) Hy is eerstens die Offerlam, as aanduiding van die lyde en offer van Christus.

(a) $\mathrm{Hy}$ is ,die Lam wat geslag is" vergelyk $5: 6 ; 5: 9$; $5: 12 ; 13: 18$.

(b) Daar is dikwels verwysing na die heilsbetekenis van „die bloed van die Lam”, (7:11), vergelyk $5: 9$; $12: 11$ ).

Hierdie gedagte aan Christus as Offerlam is volgens Sevenster $^{2}$ ) hoogswaarskynlik 'n sinspeling op die Paaslam, óf op Jes.

1) A. Richardson : a.w.. bl. 225, 226.

2) G. Sevenster: a.w.. bi. 277. 
53:7. Vir eersgenoemde pleit dat ook elders in "Openbaring" sinspeling is op die verlossing uit Egipte, byvoorbeeld in $15: 3$ (die Lied van Moses en van die Lam; vergelyk ook 1 Kor. 5: 7; John $1: 29$; $19: 33$; 1 Petr. $1: 19$ ).

Wat eens in die Paaslam aangedui is, het nou in die egte Paaslam realiteit geword. Dit is egter volgens Sevenster ook moontlik om te dink aan Jes. 53:7. (Hou in hierdie verband die genoemde standpunt van Richardson in gedagte). Albei moontlik hede dui in elke geval op die heilsbetekenis van Jesus se sterwe.

(2) Hy is ook die militêre, strydende en oorwinnende Lam, wat op die voorpunt uittrek om te veg teen die vyande van die kudde (vergelyk Henog 89 vv; Openb. 17:14; $6: 16$ toorn; $14: 10$ gerig; $3: 8$ en $21: 27$ - beskikking oor die boek van die lewe; $5: 6$ - strydbaar: horings en oё; $7: 9,10 ; 5: 13 ; 22: 1,3$ mag en heerlikheid). In al hierdie Skrifgedeeltes tree die Lam op as Stryder teen duiwelse magte, as die Aanvoerder en Herder van Sy volk (7:17; $14: 4)$, as Regter by die Laaste Oordeel. ${ }^{3}$ )

In 5: 12 word die twee voorstellings van die Lam, naamlik as Offerlam en as Strydende en Oorwinnende Lam, verenig. Vers 12 lui soos volg: „Die Lam wat geslag is, is waardig om te ontvang die krag en rykdom en wysheid en sterkte en eer en heerlikheid en lof".

Volgens Charles ${ }^{4}$ ) word hierdie doksologie geuiter op grond van die erkenning van die mag wat die Lam reeds besit, of op grond van die feit dat Hy op die punt is om dit op te neem. Lohmeyer ${ }^{5}$ ) sien die hoofstuk waaruit hierdie teks kom, as ' $n$ soort troonsbestygingsplegtigheid na analogie van ' $n$ antieke gebruik. Dit gaan om die laaste en hoogste deel van ' $n$ verlossersgeloof wat by die daad van die troonsbestyging van ' $n$ Goddelike Heerser en Regter, die begin van 'n nuwe tyd - of liewers : die einde van alle tyd vasknoop.

Die troonsbestyging vind plaas aan die einde van die tyd, maar volgens $3: 21$ het dit reeds in die verlede geskied. Dit wys egter slegs heen na die tydsbegrip wat aan elke Verlossersgeloof vasgeknoop is, waarvoor die eschatologiese gebeure as $t^{\prime}$ ware 'n openlike herhaling is van wat vir die gelowiges reeds in die historiese verlede gebeur het. ${ }^{6}$ )

3) Richardson : a.w., bl. 227v; Sevenster: a.w., bl. 278.

4) a.w., ad loc.

5) a.w., ad loc.

6) Lohmeyer: a.w., ad loc. 
Wat die Lam se verhouding tot die eerste Persoon in die Drie-eenheid betref, is dit so dat die Lam as Verlosser in die middel van Gods troon staan $(5: 6: 7: 17)$ en die troon van God, Sy troon is $(22: 1,3)$. Die Seun is die openbaring van die Vader op hierdie moment van die wêreldgeskiedenis. Goddelike almag en Goddelike liefde en Selfofferande is onlosmaaklik aan mekaar verbind tot verlossing van die wêreld. ")

Ook in verband met die aanduiding van Christus as "die Lam", kan die genoemde skema van Cullman toegepas word:

(1) Aardse werk.

Onder andere : Die Lam wat geslag is $-5: 6 ; 5: 9,12$; $7: 14 ; 13: 8$.

(2) Toekomstige werk.

Onder andere : As komende Koning en Regter-17:14; en Seun van die mens $-1: 13$.

(3) Huidige werk van die Verhoogde Jesus.

Onder andere : As Hoëpriester - 1:13.

(4) Pre-eksistensie.

Onder andere : As Seun van God - 2:18, en as Seun van die Mens - $1: 13$; vergelyk ook $3: 14$.

III Here.

1. Buite-Bybelse Gebruike van dié term. ${ }^{1}$ )

In die Oosters-Hellenistiese godsdienste en in die keiserkultus van Rome word kúrios soms as sinoniem vir despotês gebruik; vir die begrip kurios is die gedagte van legitieme outoriteit egter grondliggend, in teenstelling met despotês wat 'n element van willekeur bevat.

Die begrip heer het daar die algemene betekenis van „gebieder". „besitter". Dog dit word ook gebruik met die besondere betekenis : "dié Here" — vergelyk „Kyrios Kaisar" — in absolute religieuse $\sin$.

\section{Die Here (ho kurios) in die Jodendom. ${ }^{2}$ )}

Hierdie Griekse woord stem ooreen met die Hebreeuse "Adôn” en die Aramese "Mar". Die beslissende vraag hier is of hierdie

7) Charles : a.w., Vol. I, bl. cxiv.

1) O. Cullmann : a.w., bl. 200 vv.

2) O. Cullmann : a.w., bl. 205 vv. 
woorde in die Nuwe Testamentiese tyd in absolute sin as „die Here" gebruik is.

Konklusie: Vir die Jodendom in Palestina én in die Diaspora was Adôn-Kyrios in die Nnwe Testamentiese tyd 'n liturgiese aanduiding van God. Die oordra van die Hellenistiese gebruik van Kyrios op Jesus en die toepassing van die Kyriosuitsprake van die LXX cp Jesus, is filosofies en teologies nie 'n nuwe begin nie, maar sluit by die Aramese gebruik aan. Die inhoudelike en filosofiese skakel tussen "Mari" en kurios is dic kultiese Aramese gebod .Maranata”.

\section{Kyrios Jesus en die Oerchristendom.}

In soverre as wat hierdie titel op Jesus toegepas is, het dit sy volle betekenis eers ná die dood en opstanding van Jesus gekry, ná sy „verhoging." 3)

Die belydenis "Kyrios Jesus" is van die oudste belydenisse wat ons besit ${ }^{4}$ ) (Hand. 2:36; Rom. 10:9).

As daar tussen „Koning" en "Here” onderskei moet word, kan ons sê dat die Koningstitel die klem meer op Jesus se heerskappy oor Sy Kerk laat val, ,insofern diese die Nachfolge Israels antritt, und Christus das Königtum Israels zu seiner Erfüllung bringt"; die Kyriostitel daarenteen beklemtoon meer Jesus se heerskappy oor die heelal, oor die ganse sigbare en onsigbare skepping.

Nogtans het dié twee begrippe dieselfde betekenis op al die plekke waar die teenstelling teenoor die aansprake van die Romeinse Keiser in die besonder na vore kom (vergelyk 1 Tim. $6: 15$; Openb. $17: 4$; 1 Kor. $15: 25$ e.a.)

Die naasmekaar wees van die ".heerskappy oor die Kerk" en "die Heerskappy oor die wêreld" is kenmerkend vir die Nuwe Testamentiese begrip van die kuriotês van Jesus. ${ }^{5}$ )

Die feit dat Jesus Kyrios genoem word, impliseer dat alle erebenaminge (Würdetitel) van God Self - behalwe die Vadernaam op Jesus oorgedra kan word. Alle funksies van God, selfs die van die Skepper, word aan Jesus toegeskryf. ${ }^{6}$ )

4. Kyrios Jesus in „Openbaring”.

Hierdie uiters belangrike benaming vir Jesus, word ook in

3) O. Cullmann : a.w., bl. 209.

4) O. Cullmann : a.w., bl. 222.

5) Cullmann : a.w., bl. 228.

6) Cullmann : a.w., bi. 244. 
"Openbaring" gebruik. Ons vind geen teenstelling tussen die gebruik daarvan in hierdie boek en die in die res van die Nuwe Testament nie.

'n Verwysing na die verhoogde Christus as kúrios is byvoorbeeld onmiskenbaar in hierdie belofte : AAn hom wat oorwin, sal Ek gee om saam met My te sit op My troon, soos Ek oorwin het en saam met my Vader op sy troon gaan sit het". (3:21).

Dit is ' $n$ verwysing na Ps. 110 , een van die mees gesiteerde Ou Testamentiese uitsprake in die ganse Nuwe Testament.

Die uitspraak dat Jesus ter vervulling van die psalmwoord "aan die regterhand van God" gaan sit het, het spoedig tot terminus technicus vir die oerbelydenis „Kyrios Christos" geword. ") Die troon in die hemel, setel van die Goddelike regering oor die ganse wêreld, blyk eweseer die besit van God as van die Lam te wees (vergelyk $22: 1,3$ ). ${ }^{8}$ )

Vanuit die gebruik van die Kyrios-titel vir Jesus in hierdie boek, is daar talle aanknopingspunte vir die leer oor die aardse werk van Jesus, Sy toekomstige werk, Sy werk in die hede en Sy funksie as die pre-eksistente Seun van God, Seun van die Mens, Woord van God, ens.

IV Seun van die mens.

Hierdie besonder belangrike aanduiding vir Jesus is ook een van die weiniges wat Jesus Self as aanduiding van Homself gebruik het. ${ }^{1}$ )

In hierdie "titel" wat sy wortels in die Ou Testament het (Dan. 7:13) en in die Joodse apokaliptiese literatuur (I Henog $46: 1)$ ' $n$ belangrike rol speel, is sowel die gedagtes van plaasvervanging as van lyding geimpliseer, maar ook nog van hemelse oorsprong en pre-eksistensie. ${ }^{2}$ )

In „Openbaring" kom die uitdrukking "Seun van die Mens" voor : „en tussen die sewe kandelaars Een soos die Seun van die Mens met 'n kleed aan wat tot op die voete hang, en gegord om die bors met "n goue gordel” $(1: 13)$. „En ek het gesien, en kyk,

7) Cullmann : a.w., bl. 230.

8) Sevenster: a.w., bl. 273.

1) Cullmann : a.w.. bl. 138 vv.

2) Cullmann : a.w. bl. 138 vv; D. S. Russel : The Method and Message of Jewish Apocalyptic - S.C.M. Press 1964 - bl. 324 - 325. H. H. Rowley : The Relevance of Apokalyptic - 1963 ad loc. 
daar was ' $n$ wit wolk en een soos 'n Menseseun wat op die wolk sit, met 'n goue kroon op sy hoof en in sy hand 'n skerp sekel" (14:14; vergelyk ook $1: 7,8,9-20 ; 12: 5$ ).

Volgens Lohmeyer ${ }^{3}$ ) word die benaming "Lam" gebruik in verband met Jesus se optrede teenoor die gelowiges; "Seun van die Mens" in verband met Jesus Christus se optrede teenoor die wêreld. Ons insiens kan hierdie onderskeiding egter nie oral en skerp deurgevoer word nie (vergelyk $6: 16 ; 1: 13 \mathrm{vv}$.).

\section{Seun van God.}

Die benaming kom slegs eenmaal in "Openbaring" voor, naamlik in 2:18 "Dít sê die Seun van God wat oë het soos 'n vuurvlam, en sy voete is soos blink koper .. . " Dát Jesus die Seun van God is, word egter geïmpliseer deur verskillende tekste wat van God as die Vader van Jesus Christus spreek (1:6;2:28; $3: 5,21 ; 14: 1)$. Ook in hierdie boek dui dit die heel unieke relasie aan tussen God en Christus, wat ook in die res van die Nuwe Testament die inhoud van hierdie benaming is ${ }^{1}$ ), terwyl dit vanselfsprekend ook Sy pre-eksistensie impliseer. ${ }^{2}$ )

\section{Samevatting.}

S. P. J. J. van Rensburg ${ }^{1}$ ) vat die Christologie van die boek "Openbaring" in hoofsaak só saam : Hoewel die outeur "n Joodse Christen was, verteenwoordig hierdie boek glad nie 'n enghartige Joodse of Joods-Christelike standpunt nie. Jerusalem en die ongelowige Jode word nie geidealiseer nie $(11: 8 ; 2: 9 ; 3: 9)$. Die Lam het met Sy bloed vir Hom mense gekoop uit elke stam en taal en volk en nasie (5:9). Netso universalisties in die ontelbare skare van christene uit die heidene $(7: 9)$ naas die 144,000 verseëldes uit Israel $(7: 4)$.

Die christologie van hierdie boek verraai 'n Ou Testamentiese grondslag : Christus is "die Leeu uit die stam van Juda", „die Wortel van Dawid" (5:5), "die wortel en die geslag van Dawid, die blinkende môrester" (22:16).

Die kenmerkende beskrywing van Christus is egter "die Lam".

In $1: 13$ vv. verskyn Christus as die Seun van die mens, maar Hy word ook soos in Daniël 7:9 vv. met dieselfde woorde as God

3) a.w., bl. 119, 121.

1) Sevenster : a.w., bl. 275

2) I.v.m. Sy pre-eksistensie : vergelyk ook $3: 14 ; 1: 13 ; 14: 14 ; 19: 12,13$.

1) Afgerolde lesings : Inleiding tot die Nuwe Testament: Hebr. - Openbaring (vervola) : bl. 9, 10. 
beskrywe, as die oue van dae. Dit stem ooreen met „Openbaring“ se beskouing wat Jesus sien as Wêreldregter $(1: 18 ; 19: 1 \mathrm{v})$.

Soos God $(1: 8)$ word Jesus $(1: 17)$,die eerste en die laaste" genoem.

God en die Lam word saam aanbid (5:8v; 7:10; 22:3). $\mathrm{Hy}$ is die "Koning van die konings en die Here van die here" (19:16).

\section{Slotopmerking}

Hoewel ons hiermee aan die einde gekom het van ons huidige oorsig in breë trekke oor die christologie in die boek „Openbaring van Johannes", bly daar nog uiters belangrike aspekte van die christologie, wat nie deur ons beskryf of genoem is nie, oor.

Die christologie in hierdie boek is kleurvol uitgebeeld en laat op baie aspekte van ons geloof lig val. Wyer ondersoek is nodig. 